\title{
The Role of Akt-GSK-3 $\beta$ Signaling and Synaptic Strength in Phencyclidine-Induced Neurodegeneration
}

\author{
Gang Lei', Yan Xia' and Kenneth M Johnson*,',2 \\ 'Department of Pharmacology and Toxicology, University of Texas Medical Branch, Galveston, TX, USA; ${ }^{2}$ Center for Addiction Research, \\ University of Texas Medical Branch, Galveston, TX, USA
}

\begin{abstract}
$\mathrm{N}$-methyl-D-aspartate (NMDA) receptor antagonists such as phencyclidine (PCP) can induce positive and negative symptoms of schizophrenia in humans and related effects in rodents. PCP treatment of developing rats induces apoptotic neurodegeneration and behavioral deficits later in life that mimic some symptoms of schizophrenia. The precise mechanism of PCP-induced neural degeneration is unknown. This study used selective antagonists, siRNA, and Western analysis to investigate the role of the Akt-glycogen synthase kinase-3 $\beta$ (GSK-3 $\beta$ ) pathway in PCP-induced neuronal apoptosis in both neuronal culture and postnatal day 7 rats. PCP administration in vivo and in vitro reduced the phosphorylation of Akt ${ }^{\text {Ser427 }}$ and GSK-3 $\beta^{\text {Ser9 }}$, decreasing Akt activity and increasing GSK-3 $\beta$ activity. The alteration of Akt-GSK-3 $\beta$ signaling parallels the temporal profile of caspase- 3 activation by PCP. Reducing GSK-3 $\beta$ activity by application of selective inhibitors or depletion of GSK-3 $\beta$ by siRNA attenuates caspase-3 activity and blocks PCP-induced neurotoxicity. Moreover, increasing synaptic strength by either activation of L-type calcium channels with BAY K8644 or potentiation of synaptic NMDA receptors with either a low concentration of NMDA or bicuculline plus 4-aminopyridine completely blocks PCP-induced cell death by increasing Akt phosphorylation. These neuroprotective effects are associated with activation of phosphoinositide-3-kinase-Akt signaling, and to a lesser extent, the MAPK signaling pathway. Overall, these data suggest that PCP-induced hypofunction of synaptic NMDA receptors impairs the Akt-GSK-3 $\beta$ cascade, which is necessary for neuronal survival during development, and that interference with this cascade by PCP or natural factors may contribute to neural pathologies, perhaps including schizophrenia.

Neuropsychopharmacology (2008) 33, 1343-1353; doi: I0.1038/sj.npp. I30 I5 I I; published online I 8 July 2007
\end{abstract}

Keywords: phencyclidine; Akt; glycogen synthase kinase-3 $\beta$; schizophrenia; NMDA receptor; neurotoxicity

\section{INTRODUCTION}

Phencyclidine (PCP), like MK801 and ketamine, is a noncompetitive, use-dependent $N$-methyl-D-aspartate (NMDA) receptor antagonist or channel blocker (Anis et al, 1983). It is well known that acute administration of NMDA antagonists can induce a broad range of antipsychoticsensitive, schizophrenia-like symptomatology in both humans and rodents, findings that have greatly contributed to a hypoglutamatergic hypothesis of schizophrenia (Farber et al, 1995; Olney and Farber, 1995; Jentsch and Roth, 1999; Wang et al, 2001; Morris et al, 2005; Coyle, 2006). The schizophrenia-like behaviors have been attributed to both the acute vacuolization caused by MK-801 and PCP as well as the non-toxic temporary effects of these drugs. In addition, it has been demonstrated that NMDA antagonists administered during early development in rodents induce neurodegeneration in specific brain regions (Ikonomidou

*Correspondence: Dr KM Johnson, Department of Pharmacology and Toxicology, University of Texas Medical Branch, Galveston, TX 77555I03I, USA, Tel: + I 409772 9623, Fax: + I 409772 9642,

E-mail: kmjohnso@utmb.edu

Received 28 March 2007; revised 25 May 2007; accepted 12 June 2007 et al, 1999; Wang and Johnson, 2005) that is associated with schizophrenia-like alterations in sensorimotor gating and working memory later in life (Wang et al, 2001). PCPinduced cortical degeneration is caspase- 3 dependent and is also developmentally regulated (Ikonomidou et al, 1999; Wang and Johnson, 2005, 2007). Since schizophrenia has been recognized as a developmentally dependent disorder, the demonstration that MK801- and PCP-induced neurodegeneration is developmentally regulated lends credence to the value of this animal model and suggests that understanding the mechanism of neuronal death in this model may provide insights into the pathophysiology of schizophrenia as well as its pharmacotherapy.

It has been demonstrated recently that Akt-glycogen synthase kinase- $3 \beta$ (GSK-3 $\beta$ ) signaling may be impaired in schizophrenia. The Akt1 gene is thought to be a potential susceptibility gene for schizophrenia (Emamian et al, 2004; Kalkman, 2006; Bajestan et al, 2006). Akt is a serine/ threonine protein kinase involving diverse cellular processes (Brazil et al, 2004). GSK-3 $\beta$, the predominant brain isoform of GSK-3, is one of the downstream substrates for Akt (Song et al, 2002). Physiologically, Akt decreases GSK-3 $\beta$ activity by enhancing GSK-3 $\beta$ phosphorylation, promoting 
cell survival (Cohen and Goedert, 2004; Jope and Roh, 2006). Also, it has been shown that amphetamine-induced impairment of sensorimotor gating and working memory in prefrontal cortex is exaggerated in the Akt1-deficient mouse (Lai et al, 2006). Moreover, antipsychotics, such as haloperidol and clozapine, have been reported to enhance Akt-GSK-3 $\beta$ signaling (Kalkman, 2006).

Activation of synaptic NMDA receptors has been reported to enhance neuronal survival signaling cascades, including the phosphoinositide-3-kinase (PI-3K)-Akt pathway (Papadia et al, 2005; Soriano et al, 2006). PCP blockade prevents calcium influx through physiologically active NMDA receptors, which are typically localized at the synapse. Thus, PCP-induced neurotoxicity could result from blocking signaling through synaptic NMDA receptors. In the current study, we tested the hypotheses that PCP causes neurotoxicity via impairment of the Akt-GSK- $3 \beta$ signaling cascade subsequent to blockade of synaptic NMDA receptors, and further, that this could be prevented by activation of synaptic NMDA receptors and the PI-3K-AktGSK-3 $\beta$ pathway.

\section{MATERIALS AND METHODS}

\section{Animals and Experimental Paradigms}

Timed-pregnant Sprague-Dawley (SD) rats were obtained from Charles River Laboratories Inc. (Wilmington, MA). They were housed individually with a standard $12 \mathrm{~h}$ dark/ light cycle in a temperature- and humidity-controlled environment with free access to food and water. After parturition, the pups were kept in the same cage with their mother until postnatal day 7 (PN7), and then randomly assigned to either the control or PCP group. PCP $(10 \mathrm{mg} / \mathrm{kg})$ or saline was administered subcutaneously. The pups were killed 3, 6, or $9 \mathrm{~h}$ afterwards. The cortex, hippocampus, and striatum were dissected with the help of an ice-cold aluminum brain mold and the tissue was quickly immerged in liquid nitrogen for $30 \mathrm{~min}$ and stored at $-80^{\circ} \mathrm{C}$. For Western blots (WBs), frozen tissue was homogenized at $4^{\circ} \mathrm{C}$ in RIPA buffer (Tris $50 \mathrm{mM}, \mathrm{pH} 8.0, \mathrm{NaCl} 150 \mathrm{mM}$, EDTA $1 \mathrm{mM}, \quad 0.5 \%$ Triton-X100, $0.5 \%$ deoxycholic acid, $1 \%$ phosphatase inhibitor cocktail II, and $1 \%$ protease inhibitor cocktail). After centrifugation at $25000 \mathrm{~g}$ for $30 \mathrm{~min}$, the supernatant was collected and protein concentration was determined using the $\mathrm{BCA}^{\mathrm{TM}}$ Protein Assay Kit (Pierce, Rockford, IL). Procedures were in accordance with the guidelines outlined in the National Institutes of Health Guide for the Care and Use of the Laboratory Animals and were approved by the Institutional Animal Care and Use Committee of University of Texas Medical Branch.

\section{Primary Neuronal Culture}

Embryonic forebrains of E18-19 SD rats were dissociated in cold Hanks solution without $\mathrm{Mg}^{2+}$ or $\mathrm{Ca}^{2+}$. Cells were plated at $10 \times 10^{5}$ cells $/ \mathrm{ml}$ and grown on polylysine $(5 \mathrm{mg} /$ $\mathrm{ml}$ )-coated multi-well plates in neuorbasal medium containing $0.5 \mathrm{mM}$ L-glutamine, supplemented with $10 \%$ B27 at $37^{\circ} \mathrm{C}$ and $5 \% \mathrm{CO}_{2}$. The culture medium was replaced every 4 days. Experiments were conducted on day in vitro (DIV) 14.

\section{Cell Death ELISA}

Nucleosomal DNA fragmentation is characteristic of apoptotic nuclei. The presence of fragmented DNA was assessed by measuring DNA associated with nucleosomal histones using a specific two-site ELISA with an antihistone primary antibody and a secondary anti-DNA antibody according to the manufacturer's instructions (Roche Diagnostics Corporation, Indianapolis, IN) as described previously (Wang et al, 2005).

\section{MTT Assay}

Mitochondrial metabolism of 3-(4,5-dimethylthiazol-2-yl)2,5-diphenyltetrazolium bromide (MTT) was used as an index of mitochondrial viability. MTT solution was added to each well at a final concentration of $5 \mu \mathrm{g} / \mathrm{ml}$. The cells were incubated for $2 \mathrm{~h}$ at $37^{\circ} \mathrm{C}$. The medium containing MTT was removed, and DMSO was added to dissolve the intracellular purple formazan metabolite. Color intensity was assessed using a microplate reader at a wavelength of $590 \mathrm{~nm}$.

\section{LDH Assay}

The release of the cytosolic enzyme lactate dehydrogenase (LDH) into the medium was used as a marker of plasma membrane integrity and as an index of cell death. Following treatment of cells, the medium was collected and assayed for LDH activity with the Cytotoxicity Detection Kit (LDH) from Roche Applied Science (Indianapolis, IN). The color density was measured using a microplate reader at an absorbance wavelength of $490 \mathrm{~nm}$.

\section{WB Analysis}

Cell extracts were prepared by lysis of PBS-washed cells in RIPA buffer. After centrifugation at $20000 \mathrm{~g}$, the supernatant was collected and protein was determined using the $\mathrm{BCA}^{\mathrm{TM}}$ Protein Assay Kit (Pierce). Antibodies for $\mathrm{pAkt}^{\mathrm{Ser} 473}$, Akt, pGSK- $3 \beta^{\text {Ser9 }}$, and GSK- $3 \beta$ were purchased from Cell Signaling Technology Inc. (Beverly, MA). pAkt ${ }^{\mathrm{Ser} 473}$ monoclonal antibody does not detect Akt phosphorylated at other sites or related kinases, according to the manufacture. The antibody has been used broadly to detect pAkt ${ }^{\mathrm{Ser} 473}$ (Jacinto et al, 2006). To probe signals on the blots, the concentrations of antibodies used were $1: 1000$ for $\mathrm{pAkt}^{\mathrm{Ser} 473}$ and pGSK $^{\text {Ser9 }}$, and $1: 1500$ for Akt and GSK-3 $\beta$, respectively.

\section{siRNA}

This experiment was performed following the manufacture's instruction. Briefly, siRNA solutions were prepared by mixing $200 \mu \mathrm{l}$ of culture medium with the GSK-3 a/ $\beta$ siRNA (Cell Signaling Technology Inc.) stock solution at a final concentration of $0,50,100$, and $150 \mathrm{nM}$ and the same volume of transfection reagent without siRNA. After incubation for $5 \mathrm{~min}$, the siRNA mixture was added to cells and agitated gently to disperse siRNA evenly. The medium containing siRNA was replaced by fresh medium after $24 \mathrm{~h}$. The inhibition of GSK-3 a/ $\beta$ protein expression was examined by WB $48 \mathrm{~h}$ after initial transfection. 


\section{Statistical Analyses}

Results are presented as mean \pm SEM. Significance was determined using a Student's $t$-test or ANOVA with Dunnett's post hoc test to determine differences among more than two groups. Differences were considered significant at $P<0.05$.

\section{RESULTS}

\section{Characterization of PCP-Induced Neurotoxicity in Rat Forebrain Neuronal Culture}

Neurotoxicity caused by ketamine, PCP, and MK-801 is dependent on development with the most vulnerable time existing in the early postnatal period in rats (Ikonomidou et al, 1999; Wang and Johnson, 2005, 2007). Thus, we determined the time frame that neuronal cultures were most vulnerable to PCP. On different DIVs, forebrain cultures were treated for $48 \mathrm{~h}$ with PCP $(1 \mu \mathrm{M})$ and assessed for membrane integrity (LDH release) and mitochondrial viability (metabolism of MTT). We observed (Figure 1a) that this preparation of cultured neurons was sensitive to PCP between DIV13 and DIV18, which is consistent with previous reports (Hwang et al, 1999). In subsequent experiments, cultures were used at DIV13 or DIV14. PCP caused loss-of-membrane integrity and mitochondrial viability after $48 \mathrm{~h}$ as determined by the LDH and MTT assays, but histone-associated DNA fragmentation was evident as early as $12 \mathrm{~h}$ after PCP addition using the Cell Death ELISA assay. PCP-induced toxicity was concentrationdependent with a half maximal effect observed at $65 \pm 4.3 \mathrm{nM}$, which correlates well with its binding affinity of 50-100 nM for NMDA receptors (Johnson and Jones, 1990). As previously reported in corticostriatal slices (Wang and Johnson, 2007), PCP $(1 \mu \mathrm{M})$ caused activation of caspase-3 within $3 \mathrm{~h}$ after PCP treatment, with the peak effect observed at $12 \mathrm{~h}$ before decaying at $48 \mathrm{~h}$ (Figure 1d). It is possible that the toxic effect of PCP seen in vivo could partially result from increased extracellular dopamine (DA) secondary to inhibition of the DA transporter by PCP (Rothman et al, 1989; Alagarsamy et al, 1997). However, this is very unlikely since this neuronal culture preparation has few, if any, DA neurons. On the other hand, Seeman and Lasaga, 2005 and Seeman et al, 2005 reported that PCP has a nanomolar affinity for the high-affinity state of the D2 receptor and thus could have a direct DA-like action on these cells. To exclude this possibility, we preincubated this neuronal culture with $2 \mu \mathrm{M}$ haloperidol and $10 \mu \mathrm{M}$ SCH23390 to block DA D2-like and D1-like receptors, respectively. However, neither antagonist had any effect on cell viability measured by MTT metabolism and LDH release (data not shown).
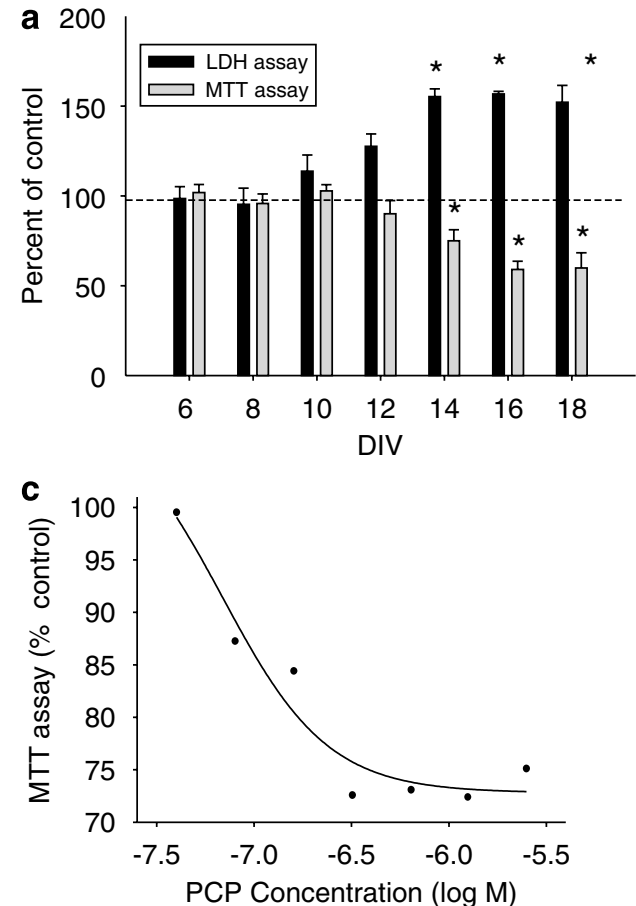

b

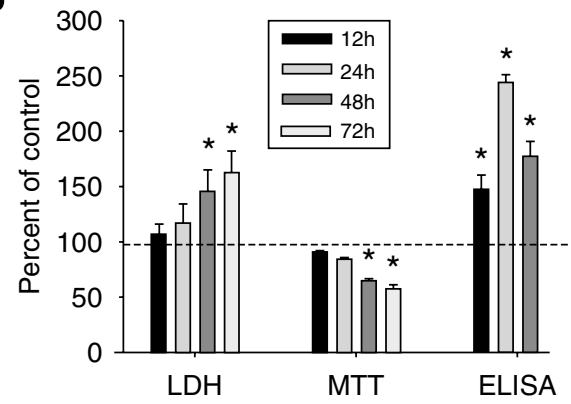

d

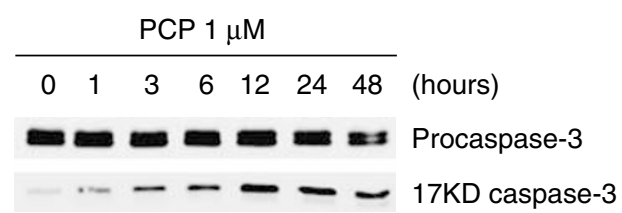

Figure I Characterization of PCP induced neurotoxicity in forebrain neuronal cultures. (a) Developmental dependence. Forebrain neurons were cultured for different times (DIV6-DIVI6) and exposed to PCP (I $\mu$ M) for $48 \mathrm{~h}$. Culture medium ( $100 \mu \mathrm{l})$ was removed from each culture plate well for assay of LDH activity. At this time, $100 \mu \mathrm{l}$ of MTT solution $(5 \mathrm{mg} / \mathrm{ml}$ ) was added to the plate and incubated for $2 \mathrm{~h}$ for assessment of MTT metabolism. (b) Cell death time course. The time course for PCP-induced cell death was determined by measuring LDH release, MTT metabolism, and nucleosomal DNA fragmentation using an ELISA at the indicated times after treatment of DIVI 4 neurons with I $\mu$ M PCP. (c) PCP concentration dependence. A series of PCP concentrations was applied to cultured neurons (DIVI4). Following $48 \mathrm{~h}$ exposure, viability was determined using the MTT assay. The dose-response curve was plotted and fitted with Sigma Plot using the four-parameter equation for sigmoidal fit. The $\mathrm{EC}_{50}$ for PCP was $65 \pm 4.25 \mathrm{nM}(\mathrm{P}<0.0 \mathrm{I})$. (d) Time course for PCP-induced cleavage of procaspase-3. Both pro- and $17 \mathrm{kDa}$ caspase-3 were probed on the same membrane. Data represent means \pm SEM for $4-6$ experiments (*P $<0.05$; compared with control of each assay used, $t$-test). 


\section{PCP Decreases Phosphorylation of Akt $\mathrm{Aer}^{\mathrm{S} 73}$}

Akt activity can be modulated by phosphorylation either on residue Thr308 or Ser473 of Akt (Brazil et al, 2004; Kumar and Madison 2005). It has been reported that phosphorylation of Thr308 is stimulated by DA receptor activation, while phosphorylation of Ser473 is regulated by NMDA receptor potentiation (Filippa et al, 1999; Brami-Cherrier et al, 2002; Papadia et al, 2005; Soriano et al, 2006). Thus, we hypothesized that PCP may decrease phosphorylation of $\mathrm{Akt}^{\mathrm{Ser} 473}$. The effect of PCP $(10 \mathrm{mg} / \mathrm{kg})$ on $\mathrm{pAkt}^{\mathrm{Ser} 473}$ expression in rat pups (PN7) is shown in Figure $2 \mathrm{a}-\mathrm{c}$. Compared with rat pups injected with saline $(10 \mathrm{ml} / \mathrm{kg})$, pAkt $^{\text {Ser473 }}$ expression was significantly decreased in the frontal cortex (Figure 2a), hippocampus (Figure 2b), and striatum (Figure 2c). The reduction of pAkt ${ }^{\mathrm{Ser} 473}$ can be observed $3 \mathrm{~h}$ after PCP injection and it does not recover even after $9 \mathrm{~h}$ in any of the three brain areas. It is unknown whether this long-lived effect of PCP is due to the continued presence of PCP or to the slow recovery of this system following the initial insult. The metabolic half-life of PCP in adults is about $4.5 \mathrm{~h}$ (Shelnutt et al, 1999), but these data are unavailable for pups at this stage of maturity. This profile of pAkt ${ }^{\text {Ser473 }}$ parallels the change in caspase- 3 activation in rat pups treated with PCP observed previously by this laboratory (Wang and Johnson, 2007). The reduction in
pAkt $^{\text {Ser473 }}$ was also observed in dissociated neuronal cultures (Figure $2 \mathrm{~d}$ and $\mathrm{e}$ ). In this preparation, the decrease of pAkt ${ }^{\mathrm{Ser} 473}$ can be measured as early as $1 \mathrm{~h}$ after PCP administration (data not shown), and remains low in the presence of PCP (Figure 2d). However, as shown in Figure 2, the total Akt protein does not change significantly either in rat pups or cultures. This suggests that Akt activity, as measured by $\mathrm{pAkt}^{\mathrm{Ser} 473}$, is substantially downregulated by PCP.

\section{Akt Inactivation Plays a Causal Role in PCP-Induced Neurotoxicity}

It has been reported that activation of L-type calcium channels (LTCCs) can increase synaptic strength and favor cell survival through facilitating calcium-dependent signaling mechanisms that propagate signals to the nucleus and regulate gene transcription and expression (Marshall et al, 2003; Yano et al, 2005; Gomez-Ospina et al, 2006). We thus proposed that activating LTCCs should block PCP-induced neurotoxicity by increasing pAkt ${ }^{\text {Ser473 }}$ expression. Cultured neurons were pretreated for $30 \mathrm{~min}$ with Bay K8644, an agonist of LTCCs, and then exposed to PCP for $48 \mathrm{~h}$. This experiment showed that Bay K8644 blocked the effect of $\mathrm{PCP}$ on $\mathrm{pAkt}^{\mathrm{Ser} 473}$ reduction in a dose-dependent manner,
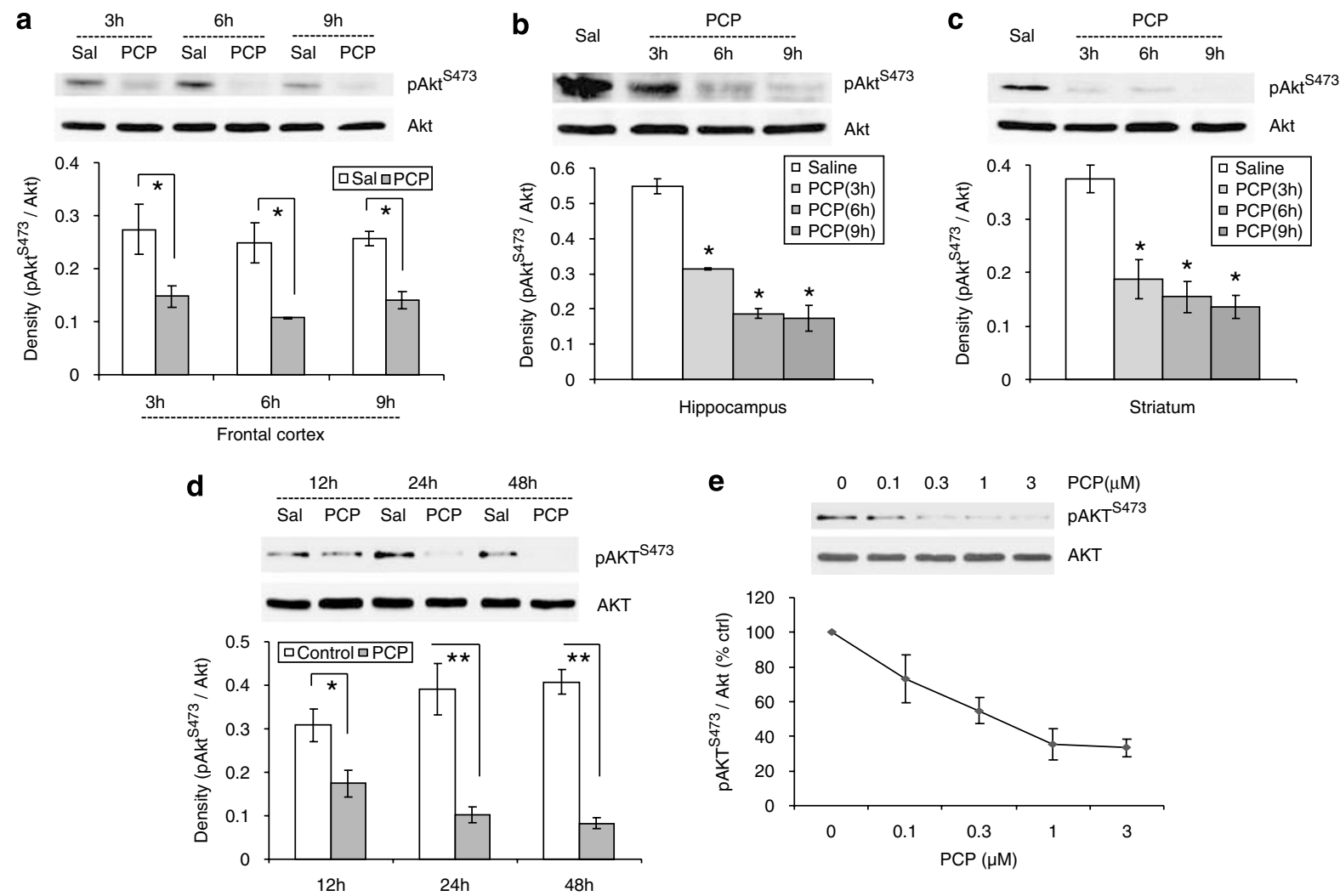

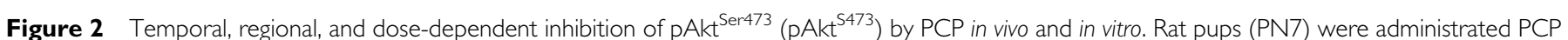

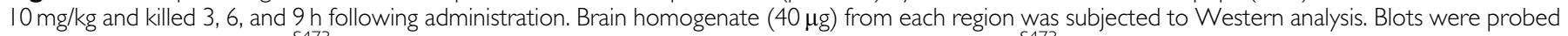

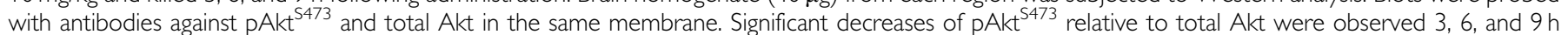

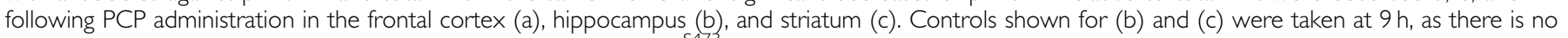

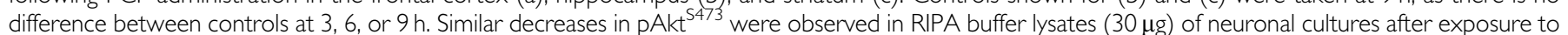

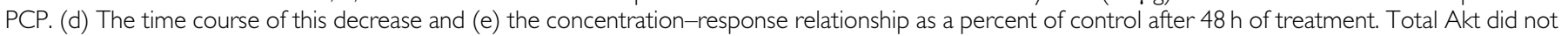

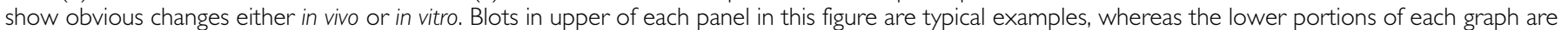
the results summarized from 3 to 5 experiments. These data represent means \pm SEM $(* P<0.05 ; * * P<0.0$ I compared with saline treatment, ANOVA). 
but did not affect total Akt (Figure 3a). Bay K8644 also prevents PCP-induced neurotoxicity in a concentration-

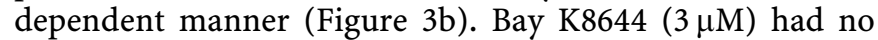
effect on either measure alone (data not shown). Thus, the protection of Bay K8644 is consistent with the activation of $\mathrm{pAkt}^{\mathrm{Ser} 473}$. To further confirm the role of Akt in Bay K8644 protection against $\mathrm{PCP}$-induced toxicity, we inhibited Akt activity by two selective Akt inhibitors (VIII and X, $2 \mu \mathrm{M}$ each). In the presence of either, the effect of Bay K8644 was completely eliminated (Figure 3c), suggesting that Akt activation is responsible for this protection. If PCP-induced neurotoxicity results from blockade of synaptic NMDA receptors, then potentiation of synaptic NMDA receptors should attenuate PCP-induced neurotoxicity. Thus, we used two approaches to activate synaptic NMDA receptors. First, $10 \mu \mathrm{M}$ NMDA, a concentration that preferentially activates synaptic NMDA receptors (Soriano et al, 2006), was added to the cultures for $24 \mathrm{~h}$. Then, after washout, the pretreated neurons were exposed to PCP and neurotoxicity was measured using both LDH and MTT assays (Figure 4a). Similarly, synaptic NMDA receptors were also activated by blocking GABAergic inhibition with co-application of bicuculline methobromide and 4-aminopyridine (4AP), a weak potassium channel blocker (Hardingham et al, 2002; Ivanov et al, 2006). These results (Figure $4 \mathrm{a}$ and b) showed that activation of synaptic NMDA receptors by either approach completely prevents PCP-induced neurotoxicity. In addition, pAkt ${ }^{\text {Ser473 }}$ expression was increased when synaptic NMDA receptors were activated by these approaches (insets in Figure $4 \mathrm{a}$ and $\mathrm{b}$ ). As elevation of synaptic strength facilitates signaling cascades such as PI-3K-Akt and Ras-MEK-ERK1/2 pathways (Papadia et al, 2005; Soriano et al, 2006), we examined the effects of selective inhibitors of PI-3K, Akt, and MAPK to further confirm that the protection emanates from activation of synaptic NMDA receptors. The protection afforded by Bic + 4-AP was abolished completely in the presence of inhibitors of either PI-3K (wortmannin or LY294002) or Akt (VIII or X) (Figure 4c). However, the effect was only partially reversed by U0126, a MAPK inhibitor, suggesting that the protection afforded by synaptic NMDA receptor activation primarily involves activation of the PI-3K-Akt pathway, though the MAPK pathway may also play a role.

\section{The Role of pGSK- $3 \beta^{\text {Ser9 }}$ in PCP-Induced Neurotoxicity}

Akt is one of principal kinase regulators of $\mathrm{GSK}-3 \beta$, inhibiting GSK-3 $\beta$ activity by phosphorylation of Ser9 on $\mathrm{N}$ terminus of GSK-3 $\beta$ (Cohen and Frame, 2001). Blockade of NMDA receptors has been shown to decrease pAkt ${ }^{\text {Ser473 }}$ (Figure 2), resulting in inactivation of Akt. Consequently, GSK- $3 \beta$ phosphorylation would be expected to be decreased
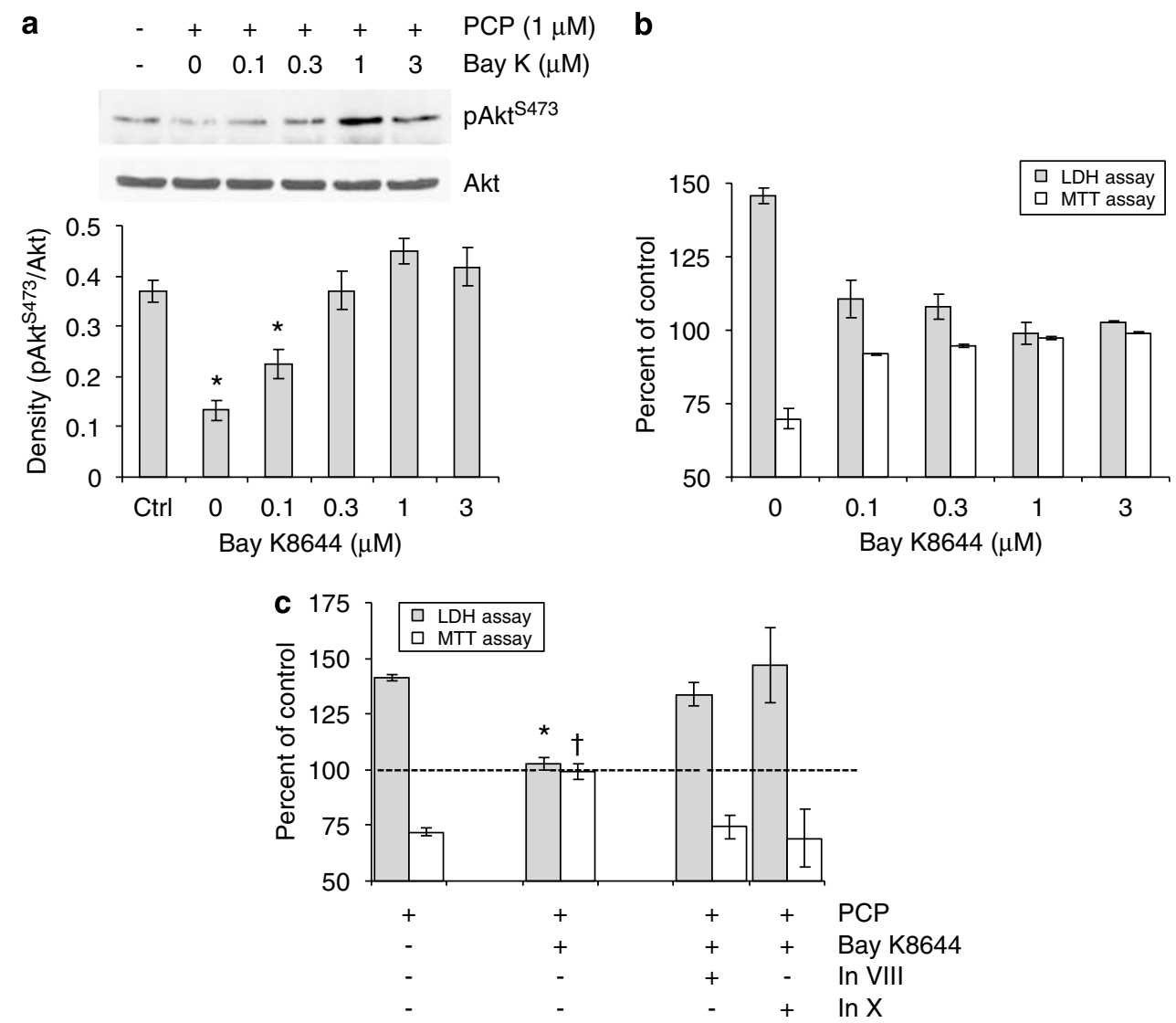

Figure 3 Activation of Akt by Bay K8644, an LTCC agonist, reverses PCP-induced neurotoxicity. Cultured neurons were pretreated with a series of Bay K8644 concentrations for $30 \mathrm{~min}$ and then exposed to PCP for $24 \mathrm{~h}$ for analysis of Akt phosphorylation (a), or $48 \mathrm{~h}$ in the presence or absence of various concentrations of Bay K8644 (b). (c) The reversal of the protective effects of $3 \mu \mathrm{M}$ Bay K8644 by 60 min pretreatment with inhibitors of Akt, VIII ( $2 \mu \mathrm{M})$ or X $(2 \mu \mathrm{M})$. Cell viability was measured by LDH release and MTT metabolism after $48 \mathrm{~h}$. These data are from four experiments $(* P<0.05$, compared with $p A k t /$ Akt control and LDH release in cells treated with PCP; ${ }^{\dagger} P<0.05$, compared with MTT assay in PCP-treated cells, $t$-test). 

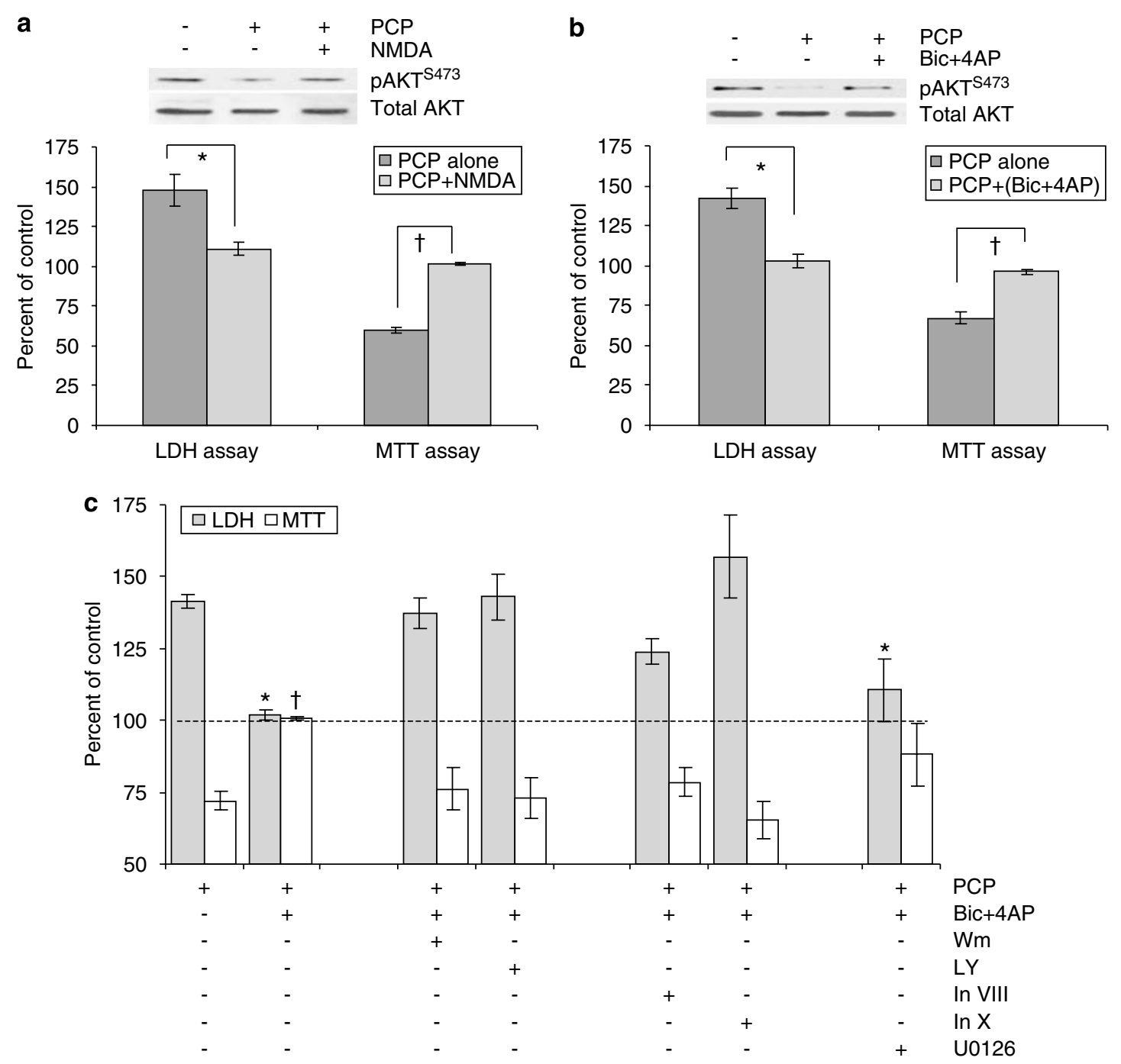

Figure 4 Activation of synaptic NMDA receptors prevents PCP-induced neurotoxicity. Cultured neurons were treated with either bath application of NMDA $(I 0 \mu \mathrm{M})$ for $24 \mathrm{~h}$, followed by washout and replacing with fresh medium (a) or the addition of bicuculline (50 $\mu \mathrm{M})$ plus 4 -aminopyridine $(25 \mu \mathrm{M})($ Bic $+4-A P$ ) overnight (b). Treated cells were exposed to PCP for $48 \mathrm{~h}$, followed by examining the cell viability. Insets in (a) and (b) show the effects of these treatments on pAkt ${ }^{\mathrm{ser} 473}$ (pAkt ${ }^{\mathrm{S} 73}$ ) protein by WB. (c) The role of PI-3K, Akt, and MAPK in the neuroprotection afforded by treatment of cultured neurons with Bic + 4-AP for $24 \mathrm{~h}$ to activate synaptic NMDA receptors was examined by treatment with the Pl-3K inhibitors, wortmannin $(0.15 \mu \mathrm{M})$ or $\mathrm{LY} 294002$ $(\mathrm{I} 50 \mu \mathrm{M})$, the Akt inhibitor, IIIV $(2 \mu \mathrm{M})$ or $\mathrm{X}(2 \mu \mathrm{M})$, and the MAPK inhibitor, U0I26 (5 $\mu \mathrm{M})$ for 60 min before PCP treatment for $48 \mathrm{~h}$. Cell viability was determined and summarized from four independent experiments. Data represent mean \pm SEM $(* P<0.05$, compared with LDH in cells treated with PCP alone; ${ }^{\dagger} P<0.05$, compared with MTT in PCP-treated cells, $t$-test).

and its activity increased as a result. GSK-3 $\beta$ has been shown to act as an apoptosis-inducing kinase in the nervous system (Hetman et al, 2002; Szatmari et al, 2005; Rivero Vaccari et al, 2006). Accordingly, we proposed that PCP would decrease the expression of pGSK-3 $\beta^{\text {Ser9 }}$ (increasing its activity), an effect that could account for PCP-induced neurotoxicity. First, rat pups (PN7) were treated with PCP and tissues were collected from rat brain as described for Akt measurements. In parallel with alteration of $\mathrm{pAkt}^{\mathrm{Ser} 473}$ by PCP, pGSK-3 $\beta^{\text {Ser9 }}$ was shown to be substantially decreased following PCP either in vivo or in vitro (Figure 5). Both the frontal cortex (Figure 5a) and the hippocampus (Figure 5b) showed marked PCP-induced reductions in pGSK- $3 \beta^{\text {Ser9 }}$, but in striatum the decrease of pGSK- $3 \beta^{\text {Ser9 }}$ was more evident (Figure $5 \mathrm{c}$ ), with the ratio of pGSK-3 $\beta^{\text {Ser9 }}$ / total GSK- $3 \beta$ being 0.161 and 0.151 for 6 and $9 \mathrm{~h}$ exposure, while these ratios were only 0.55 and 0.40 for the hippocampus and 0.33 and 0.25 for frontal cortex, respectively, over the same time frame. The reason for these regional differences is unknown. Interestingly, it agrees with a previous report from this laboratory that the striatum was more vulnerable to acute PCP exposure (Wang and Johnson, 2005). Second, cultured neurons were exposed to PCP and it was also found to robustly reduce pGSK- $3 \beta^{\text {Ser9 }}$ (Figure 5d). It has been reported that caspase-3 activation plays a major role in PCP-induced neurotoxicity (Wang and Johnson, 2007). Caspase-3 is downstream of, and activated by, GSK-3 $\beta$ (Song et al, 2002). Therefore, we examined in cultured neurons the relationship between GSK-3 $\beta$ and caspase- 3 activation. These results demonstrated that the pGSK- $3 \beta^{\text {Ser9 }}$ reduction can be observed $1 \mathrm{~h}$ after PCP treatment with the peak between 12 and $24 \mathrm{~h}$, which correlates well to temporal profiles of caspase-3 activation (Figure 5e). 

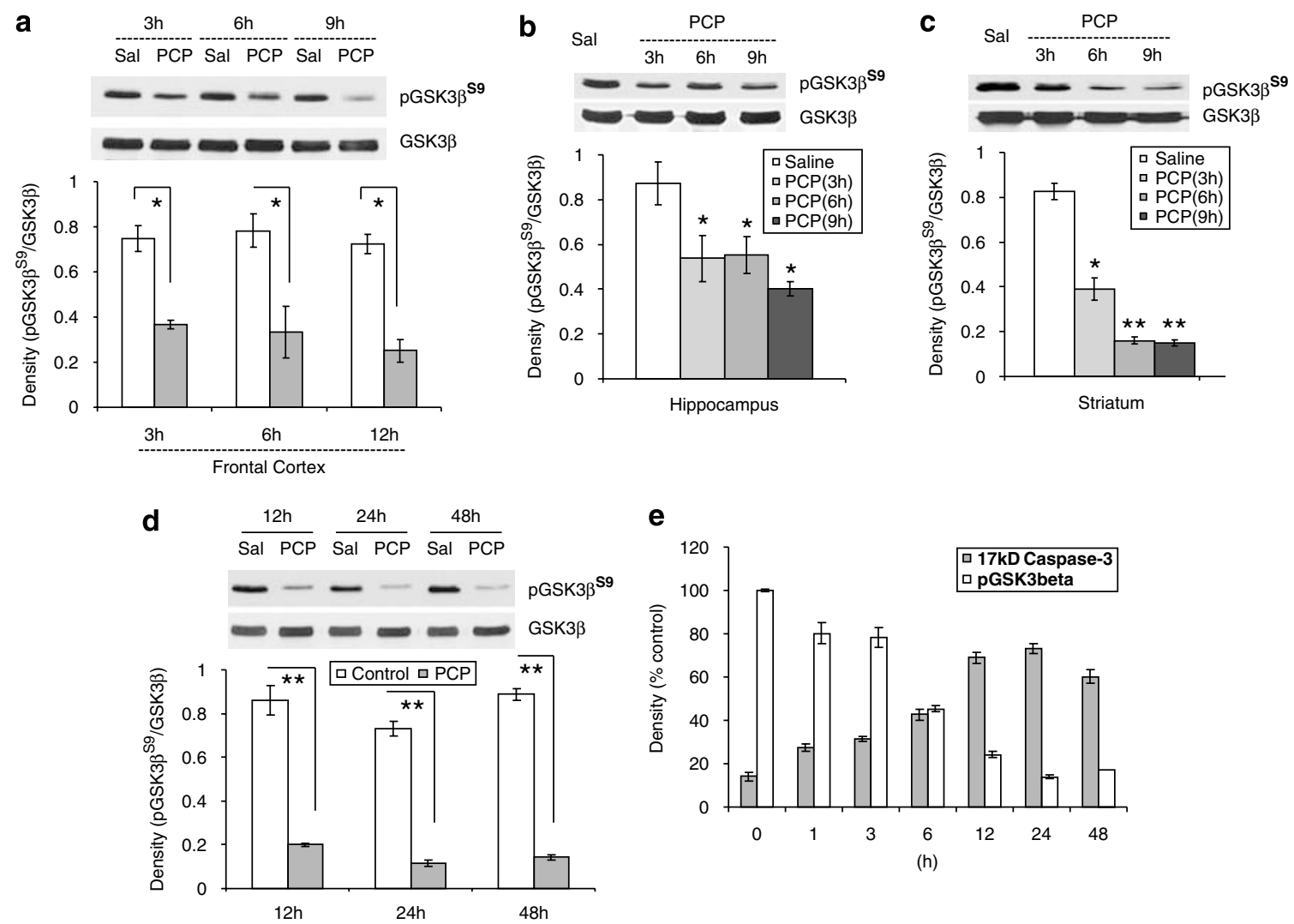

Figure 5 PCP decreases $p G S K-3 \beta^{\text {Ser9 }}\left(p G S K-3 \beta^{S 9}\right.$ ) in vivo and in vitro. Rat pus and cultured cells were treated as described for the Akt experiment in the legend of Figure 2. A decrease in PGSK-3 $\beta^{\text {S9 }}$ was found in the frontal cortex (a), hippocampus (b), and striatum (c), as well as in cultured neurons (d) compared with saline treatment. Control values for (b) and (c) are taken at $9 \mathrm{~h}$. Examples of WBs are shown in the upper portion of panels a, b, c, and d. Summary data are shown from 3 to 5 experiments in the lower portion of each corresponding panel. No significant change of total GSK-3 $\beta$ was found. (e) The relative density of activated $(17 \mathrm{kDa})$ caspase- 3 and $\mathrm{pGSK}-3 \beta^{59}$ in WBs from cell lysates $(30 \mu \mathrm{g})$ from cultured neurons treated with I $\mu \mathrm{M}$ PCP for different times $(0-48 \mathrm{~h})$. These data were summarized from three independent experiments $(* P<0.05$; $* * P<0.0$ l; compared with saline control, ANOVA).

To further clarify the role of GSK-3 $\beta$ in PCP-induced neurotoxicity, we tested two relatively selective GSK-3 $\beta$ inhibitors, lithium chloride and kenpaullone. PCP-induced neurotoxicity was completely reversed by either lithium chloride or kenpaullone (Figure 6a). In terms of inhibitor selectivity, lithium chloride has been reported to inhibit several other protein kinases, such as PKA, Akt, PKC, etc with only slightly less potency than that for GSK-3 $\beta$ (Davies et al, 2000). Similarly, kenpaullone, which has an $\mathrm{IC}_{50}$ of $0.23 \mu \mathrm{M}$ for GSK- $3 \beta$ and $0.67 \mu \mathrm{M}$ for CDK2/cyclin A (Bain et al, 2003). To exclude the potential non-selective effects of these inhibitors, we used a 48 -h treatment with siRNA directed against GSK-3 to verify the role of GSK-3 $\beta$ in PCPinduced neurotoxicity. GSK- $3 \beta$ expression was shown to be significantly inhibited by $100 \mathrm{nM}$ GSK-3 siRNA and was nearly completely suppressed by $150 \mathrm{nM}$ (Figure 6b). Caspase- 3 activation and consequent neuronal apoptosis induced by PCP were essentially prevented by GSK-3 siRNA $(150 \mathrm{nM})$ (Figure $6 \mathrm{c}$ and $\mathrm{d}$ ).

\section{DISCUSSION}

These data significantly expand on recent work demonstrating that ketamine-induced apoptosis in culture was attenuated by GSK-3 inhibitors (Takadera et al, 2006).
The current study demonstrates that PCP-induced cell death results from blockade of synaptic NMDA receptors and that this can be prevented by enhancing synaptic strength. Inhibition of the PI3K-Akt-GSK-3 $\beta$ signaling pathway plays major role in neurodegeneration caused by PCP or other NMDA channel blockers. Activation of Akt by stimulating synaptic NMDA receptors or by activating calcium influx through LTCCs favors cell survival. It was also shown that PCP-induced neurotoxicity can be prevented by blocking GSK-3 $\beta$ dephosphorylation by lithium and other selective GSK-3 $\beta$ antagonists, including siRNA. Finally, the present data provide a mechanism by which NMDA receptor hypofunction could lead to neuronal death during development. If this was of sufficient magnitude, it could lead to behavioral abnormalities later in life and could reasonably contribute to the behavioral pathology associated with schizophrenia.

It has been reported that caspase- 3 can be activated by low $\left[\mathrm{Ca}^{2+}\right]_{\mathrm{i}}$, and that NMDAR antagonists lead to reduction of $\left[\mathrm{Ca}^{2+}\right]_{\mathrm{i}}$, activation of caspase-3, and cell death (Han et al, 2001; Takadera et al, 1999; Turner et al, 2002; Yoon et al, 2003). However, whether PCP-induced reduction of $\left[\mathrm{Ca}^{2+}\right]_{i}$ is actually the cause of caspase- 3 activation and subsequent cell death is uncertain and there is some debate about the reduction of $\left[\mathrm{Ca}^{2+}\right]_{i}$. For example, Canzoniero et al (2004) showed that cultures treated with MK801 and CNQX for 


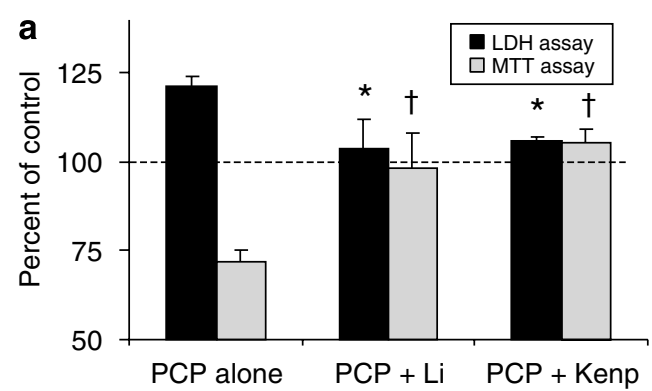

C

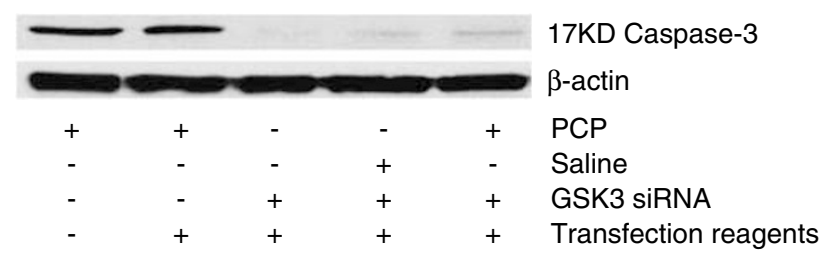

b
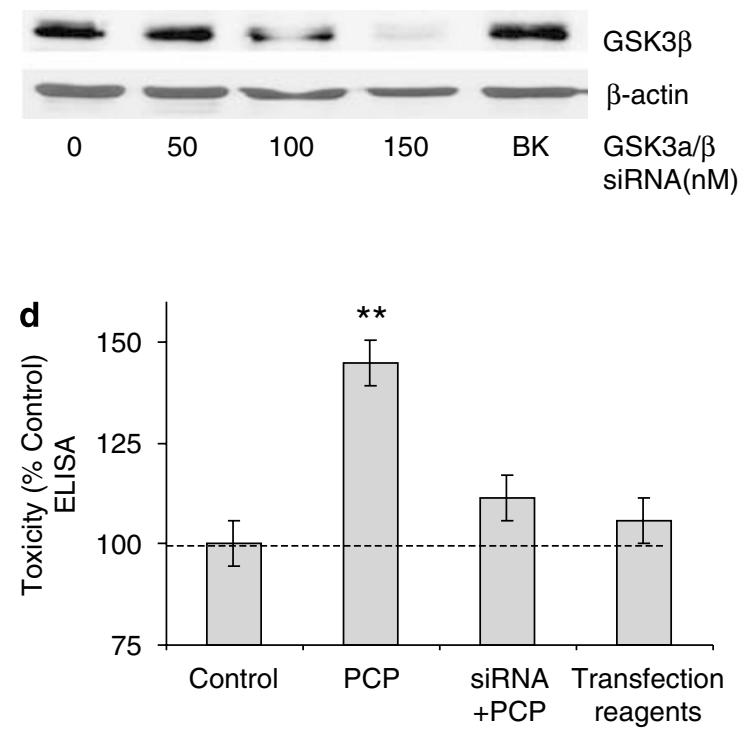

Figure 6 GSK-3 $\beta$ inhibition prevents PCP-induced neurotoxicity and caspase-3 activation. (a) Cultured neurons were pretreated for I $\mathrm{h}$ with the selective GSK-3 $\beta$ inhibitors, lithium chloride $(2 \mathrm{mM})$, or kenpaullone $(5 \mu \mathrm{M})$, and then exposed to PCP for $48 \mathrm{~h}$. The summary data shown in (a) are from four experiments. (b) This WB shows that GSK-3 siRNA diminished GSK-3 $\beta$ expression in a concentration-dependent manner. Cultured neurons were transfected with the indicated concentration of GSK-3a/ $\beta$ siRNA, lysed after $48 \mathrm{~h}$ incubation, and subjected to WB using an antibody against total GSK-3 $\beta$ to examine the effect of silencing of GSK-3 $\beta$ expression. $\beta$-Actin was used for a loading control and siRNA specificity. Cells (DIVI2) were transfected with I $50 \mathrm{nM}$ of GSK-3 $\beta$ siRNA and incubated in culture medium for $48 \mathrm{~h}$, followed by exposure to PCP for $24 \mathrm{~h}$. Activated caspase- 3 was determined by WB using cell lysate ( $30 \mu \mathrm{g}$ protein) from culture neurons transfected with siRNA (c), and neuronal viability was determined by a Cell Death ELISA kit using the same neuronal lysate $\left({ }^{*} P<0.05\right.$, compared with LDH release in PCP group; ${ }^{\dagger} P<0.05$, compared with MTT in PCP group; ${ }^{* *} P<0.0$ I, compared with control in Cell Death ELISA, t-test).

110 min did not exhibit any decrease in $\left[\mathrm{Ca}^{2+}\right]_{\mathrm{i}}$. The reason for this apparent conflict is unknown, but the route of $\mathrm{Ca}^{2+}$ entry and subsequent subcellular compartmentalization may play a critical role in determining which signaling pathways are activated. Calcium entry through LTCCs activates Akt (Murphy et al, 1991) and various transcription factors and kinases such as CREB, BDNF, IGF-1, PI-3K, Akt, and Src (Blair and Marshall, 1997; Graef et al, 1999; Dolmetsch et al, 2001; Ikegami and Koike, 2000) which, in turn, help to determine cell fate (Morgan and Curran, 1986; Mao et al, 1999). This may explain why inhibition of Akt can block the protection afforded by LTCCs. Furthermore, $\mathrm{Ca}^{2+}$ entry through synaptic NMDA receptors may induce CREB activity and BDNF gene expression, while $\mathrm{Ca}^{2+}$ entry through extrasynaptic NMDA receptors is known to activate a general and dominant CREB shut-off pathway that blocks the induction of $B D N F$ expression (Hardingham et al, 2002). Thus, blockade of synaptic calcium entry may well be injurious, but blockade of extrasynaptic $\mathrm{Ca}^{2+}$ entry could even be protective by preventing NMDA receptor-mediated loss of mitochondrial membrane potential and cell death (Hardingham et al, 2002; Vanhoutte and Bading, 2003). Therefore, a simple reduction in intracellular $\mathrm{Ca}^{2+}$ is insufficient to fully explain the mechanism of cell death resulting from NMDAR blockade.

Enhancement of synaptic strength activates cell survival signaling cascades, such as the PI-3K-Akt and Ras-MEKERK1/2 pathways, promoting long-term neuroprotection against a variety of insults, including trophic deprivation and protein kinase inhibition (Soriano et al, 2006; Ivanov et al, 2006). Blockade of NMDA receptors can impair synaptic plasticity, eliminating signaling through the NMDA receptor. Hansen et al (2004) demonstrated that administration of MK801 to rat pups (PN7) led to reduced levels of BDNF and subsequent signaling through Ras-MEKERK in brain regions displaying apoptosis. Although exogenous BDNF prevented MK801-induced toxicity in that study, transgenic Ras activation only prevented about $40 \%$ of MK801-induced neurotoxicity (Hansen et al, 2004), strongly suggesting the existence of other pathways, such as the activation of Akt-GSK-3 $\beta$ signaling as implicated in the current study. Although not investigated here, activation of this pathway could provide protection through its phosphorylation and inhibition of proapoptotic mediators such as Bad, FOXO family members, I $\kappa$ B kinase- $\beta$ (Datta et al, 1999). Moreover, Akt phosphorylates GSK-3 $\beta$ with the consequence of reducing GSK- $3 \beta$ activity and favoring cell survival.

Activation of GSK-3 $\beta$ has been reported to promote apoptosis in a wide variety of conditions (Bijur and Jope, 2001; Jope and Johnson, 2004). Previous reports have demonstrated that blockade of NMDA receptors results in an increase in proapoptotic $B a x$ and a decrease in antiapoptotic $\mathrm{Bcl}-\mathrm{X}_{\mathrm{L}}$ and $\mathrm{Bcl}_{2}$ (Wang et al, 2000; Hansen et al, 2004). Moreover, it has been shown that GSK-3 $\beta$ can activate Bax by direct phosphorylation of $B a x-\alpha$ on serine 163 , a residue found within a putative GSK- $3 \beta$ phosphorylation motif (Linseman et al, 2004). This suggests that 
GSK-3 $\beta$ may exert its proapoptotic effects in neurons by modifying $\mathrm{Bcl}_{2}$ family member expression, which, in turn, can lead to impairment of mitochondrial membrane potential, cytochrome $c$ release, and caspase- 3 activation.

Akt phosphorylation could also play a role in integrating input from both dopaminergic and glutamatergic influences and, as such, could be a key player in the pathogenesis of schizophrenia. Two key phosphorylation sites, Thr308 and Ser473, are critical in regulating Akt activity (Brazil et al, 2004; Kumar and Madison, 2005). These modifications have been reported to involve different signaling pathways. Activation of Akt by phosphorylation of Thr308 is PI-3K independent, and regulated by PKA (cAMP-dependent protein kinase) (Filippa et al, 1999), while Brami-Cherrier et al (2002) showed that DA D1 and D2 agonists increase phosphorylation levels of Akt on Thr308 (but not Ser473), independently of PI-3K signaling. Furthermore, Beaulieu et al (2004) proposed that increased DA neurotransmission in mouse striatum activates an alternative pathway involving phosphorylation of pAktThr308 and subsequent phosphorylation of GSK-3 $\alpha / \beta S 21 / 9$. Interestingly, activation of NMDA receptors also increases Akt activity, but by phosphorylation of Ser473 rather than Thr308. Opposite to DA activation, NMDA receptors activation occurs in a PI3K-dependent manner (Sutton and Chandler, 2002; Papadia et al, 2005; Soriano et al, 2006). The current study demonstrates that blockade of NMDA receptors by PCP decreases Akt activity by reducing $\mathrm{pAkt}^{\mathrm{Ser} 473}$ and increases GSK- $3 \beta$ activity by reducing pGSK- $3 \beta^{\text {Ser } 9}$. Importantly, this effect of PCP, as well as PCP's neurotoxicity, can be reversed by increasing the activity of synaptic NMDA receptors, thereby supporting the hypothesis that PCP's effects are mediated by blockade of synaptic, rather than extrasynaptic, NMDA receptors. This dual regulation of phosphorylation of Akt and GSK- $3 \beta^{\text {Ser9 }}$ could be important in both the etiology and therapy of schizophrenia (Kalkman, 2006; Kozlovsky et al, 2006).

It should be mentioned that these data appear to contradict two previous studies showing that administration of PCP or MK801 to adult mice or rats increased $\mathrm{pAkt}^{\text {Ser473 }}$ and/or pGSK-3 $\beta^{\text {Ser9 }}$ (Svenningsson et al, 2003; Ahn et al, 2005). This difference could be due to the difference between adults and developing rat pups, but it also could be explained by a biphasic dose response to MK801. That is, Ahn et al (2005) reported that doses up to $1 \mathrm{mg} / \mathrm{kg}$ MK801 increased pAkt ${ }^{\text {Ser473, but higher doses }}$ resulted in a decrease in pAkt $\mathrm{pr}^{\mathrm{Se} 43}$. Thus, it is likely that the dose of PCP used in this study corresponds to the higher doses of the more potent MK801 used by Ahn et al (2005).

Further study of Akt-GSK-3 $\beta$ signaling and its role in various animal models of schizophrenia appear to be a promising approach to the discovery of novel therapeutics for schizophrenia and possibly related illnesses such a mania. Altered Akt-GSK-3 $\beta$ signaling cascade has been implicated in the pathogenesis of schizophrenia (Norton et al, 2006; Ross et al, 2006) and it has been demonstrated that GSK-3 $\beta$ is substantially lower in post-mortem frontal cortex of schizophrenics (Kozlovsky et al, 2002, 2005). Also, Emamian et al (2004) reported that pGSK-3 $\beta^{\text {Ser9 }}$ and Akt1 were significantly decreased in the peripheral lymphocytes and brains of schizophrenics. This group also reported an association between schizophrenia and an Aktl haplotype associated with lower Akt protein levels and a greater sensitivity to the sensorimotor gating-disruptive effect of amphetamine. This supports the notion that defective Akt1GSK-3 $\beta$ signaling could contribute to the pathogenesis of schizophrenia. In fact, an association of the Aktl gene with schizophrenia has been reported in Japanese (Ikeda et al, 2004), European (Schwab et al, 2005), and Iranian populations (Bajestan et al, 2006), although other studies have not replicated these observations (Ohtsuki et al, 2004; Ide et al, 2006). In addition, Lai et al (2006) reported that Akt1deficient mice displayed altered prefrontal neuronal architecture and also abnormal performance in a working memory task, generally regarded as a core feature of schizophrenia (Lewis and Gonzalez-Burgos, 2006). Thus, the current study supports the potential role of altered Akt1-GSK-3 $\beta$ signaling in schizophrenia and suggests that further study of the molecular mechanisms of NMDA receptor regulation of this pathway could provide additional useful insights into the pathology and treatment of this disease and potentially other neurodegenerative diseases as well.

\section{ACKNOWLEDGEMENTS}

We are grateful to Dr Chengzhong Wang and Ms Noelle C Anastasio for helpful discussion and comments. This work was supported by Grants DA-02073 and MH-63871 from the US Department of Health and Human Services.

\section{FINANCIAL DISCLOSURES/CONFLICT OF INTEREST}

Dr Lei reports no biomedical financial interests or potential conflicts of interest. Ms Xia reports no biomedical financial interests or potential conflicts of interest. Dr Johnson reports no biomedical financial interests or potential conflicts of interest.

\section{REFERENCES}

Ahn YM, Seo MS, Kim SH, Kim Y, Yoon SC, Juhnn YS et al (2005). Increased phosphorylation of Ser473-Akt, Ser9-GSK-3beta and Ser133-CREB in the rat frontal cortex after MK-801 intraperitoneal injection. Int J Neuropsychopharmacol 8: 607-613.

Alagarsamy S, Phillips M, Pappas T, Johnson KM (1997). Dopamine neurotoxicity in cortical neurons. Drug Alcohol Depend 48: 105-111.

Anis NA, Berry SC, Burton NR, Lodge D (1983). The dissociative anaesthetics, ketamine and phencyclidine, selectively reduce excitation of central mammalian neurons by $N$-methyl-aspartate. Br J Pharmacol 79: 565-575.

Bain J, McLauchlan H, Elliott M, Cohen P (2003). The specificities of protein kinase inhibitors: an update. Biochem J 371: 199-204.

Bajestan SN, Sabouri AH, Nakamura M, Takashima H, Keikhaee MR, Behdani F et al (2006). Association of AKT1 haplotype with the risk of schizophrenia in Iranian population. Am J Med Genet B Neuropsychiatr Genet 141: 383-386.

Beaulieu JM, Sotnikova TD, Yao WD, Kockeritz L, Woodgett JR, Gainetdinov RR et al (2004). Lithium antagonizes dopaminedependent behaviors mediated by an AKT/glycogen synthase kinase 3 signaling cascade. Proc Natl Acad Sci USA 101: 5099-5104. 
Bijur GN, Jope RS (2001). Proapoptotic stimuli induce nuclear accumulation of glycogen synthase kinase-3 beta. J Biol Chem 276: 37436-37442.

Blair LA, Marshall J (1997). IGF-1 modulates N and L calcium channels in a PI 3-kinase-dependent manner. Neuron 19: 421-429.

Brami-Cherrier K, Valjent E, Garcia M, Pages C, Hipskind RA, Caboche J (2002). Dopamine induces a PI3-kinase-independent activation of Akt in striatal neurons: a new route to cAMP response element-binding protein phosphorylation. J Neurosci 22: 8911-8921.

Brazil DP, Yang ZZ, Hemmings BA (2004). Advances in protein kinase B signalling: AKTion on multiple fronts. Trends Biochem Sci 29: 233-242.

Canzoniero LM, Babcock DJ, Gottron FJ, Grabb MC, Manzerra P, Snider BJ et al (2004). Raising intracellular calcium attenuates neuronal apoptosis triggered by staurosporine or oxygenglucose deprivation in the presence of glutamate receptor blockade. Neurobiol Dis 15: 520-528.

Cohen P, Frame S (2001). The renaissance of GSK-3. Nat Rev Mol Cell Biol 2: 769-776.

Cohen P, Goedert M (2004). GSK-3 inhibitors: development and therapeutic potential. Nat Rev Drug Discov 3: 479-487.

Coyle JT (2006). Glutamate and schizophrenia: beyond the dopamine hypothesis. Cell Mol Neurobiol 26: 363-382.

Datta SR, Brunet A, Greenberg ME (1999). Cellular survival: a play in three Akts. Genes Dev 13: 2905-2927.

Davies SP, Reddy H, Caivano M, Cohen P (2000). Specificity and mechanism of action of some commonly used protein kinase inhibitors. Biochem J 351: 95-105.

Dolmetsch RE, Pajvani U, Fife K, Spotts JM, Greenberg ME (2001). Signaling to the nucleus by an L-type calcium channelcalmodulin complex through the MAP kinase pathway. Science 294: 333-339.

Emamian ES, Hall D, Birnbaum MJ, Karayiorgou M, Gogos JA (2004). Convergent evidence for impaired AKT1-GSK-3beta signaling in schizophrenia. Nat Genet 36: 131-137.

Farber NB, Wozniak DF, Price MT, Labruyere J, Huss J, St Peter H et al (1995). Age-specific neurotoxicity in the rat associated with NMDA receptor blockade: potential relevance to schizophrenia? Biol Psychiatry 38: 788-796.

Filippa N, Sable CL, Filloux C, Hemmings B, Van Obberghen E (1999). Mechanism of protein kinase B activation by cyclic AMPdependent protein kinase. Mol Cell Biol 19: 4989-5000.

Gomez-Ospina N, Tsuruta F, Barreto-Chang O, Hu L, Dolmetsch R (2006). The C terminus of the L-type voltage-gated calcium channel $\mathrm{Ca}(\mathrm{V}) 1.2$ encodes a transcription factor. Cell 127: 591-606.

Graef IA, Mermelstein PG, Stankunas K, Neilson JR, Deisseroth K, Tsien RW et al (1999). L-type calcium channels and GSK-3 regulate the activity of NF-ATc4 in hippocampal neurons. Nature 401: 703-708.

Han KS, Kang HJ, Kim EY, Yoon WJ, Sohn S, Kwon HJ et al (2001). 1,2 -bis(2-aminophenoxy)ethane- $N, N, N^{\prime}, N^{\prime}$-tetraacetic acid induces caspase-mediated apoptosis and reactive oxygen speciesmediated necrosis in cultured cortical neurons. J Neurochem 78: 230-239.

Hansen HH, Briem T, Dzietko M, Sifringer M, Voss A, Rzeski W et al (2004). Mechanisms leading to disseminated apoptosis following NMDA receptor blockade in the developing rat brain. Neurobiol Dis 16: 440-453.

Hardingham GE, Fukunaga Y, Bading H (2002). Extrasynaptic NMDA receptors oppose synaptic NMDA receptors by triggering CREB shut-off and cell death pathways. Nat Neurosci 5: 405-414.

Hetman M, Hsuan SL, Habas A, Higgins MJ, Xia Z (2002). ERK1/2 antagonizes glycogen synthase kinase-3beta-induced apoptosis in cortical neurons. J Biol Chem 277: 49577-49584.
Hwang JY, Kim YH, Ahn YH, Wie MB, Koh JY (1999). N-methyl-Daspartate receptor blockade induces neuronal apoptosis in cortical culture. Exp Neurol 159: 124-130.

Ide M, Ohnishi T, Murayama M, Matsumoto I, Yamada K, Iwayama $\mathrm{Y}$ et al (2006). Failure to support a genetic contribution of AKT1 polymorphisms and altered AKT signaling in schizophrenia. J Neurochem 99: 277-287.

Ikeda M, Iwata N, Suzuki T, Kitajima T, Yamanouchi Y, Kinoshita $\mathrm{Y}$ et al (2004). Association of AKT1 with schizophrenia confirmed in a Japanese population. Biol Psychiatry 56: 698-700.

Ikegami K, Koike T (2000). Membrane depolarization-mediated survival of sympathetic neurons occurs through both phosphatidylinositol 3-kinase- and CaM kinase II-dependent pathways. Brain Res 866: 218-226.

Ikonomidou C, Bosch F, Miksa M, Bittigau P, Vockler J, Dikranian $\mathrm{K}$ et al (1999). Blockade of NMDA receptors and apoptotic neurodegeneration in the developing brain. Science 283: 70-74.

Ivanov A, Pellegrino C, Rama S, Dumalska I, Salyha Y, Ben Ari Y et al (2006). Opposing role of synaptic and extrasynaptic NMDA receptors in regulation of the extracellular signal-regulated kinases (ERK) activity in cultured rat hippocampal neurons. J Physiol 572: 789-798.

Jacinto E, Facchinetti V, Liu D, Soto N, Wei S, Jung SY et al (2006). SIN1/MIP1 maintains rictor-mTOR complex integrity and regulates Akt phosphorylation and substrate specificity. Cell 127: $125-137$.

Jentsch JD, Roth RH (1999). The neuropsychopharmacology of phencyclidine: from NMDA receptor hypofunction to the dopamine hypothesis of schizophrenia. Neuropsychopharmacology 20: 201-225.

Johnson KM, Jones SM (1990). Neuropharmacology of phencyclidine: basic mechanisms and therapeutic potential. Annu Rev Pharmacol Toxicol 30: 707-750.

Jope RS, Johnson GV (2004). The glamour and gloom of glycogen synthase kinase-3. Trends Biochem Sci 29: 95-102.

Jope RS, Roh MS (2006). Glycogen synthase kinase-3 (GSK-3) in psychiatric diseases and therapeutic interventions. Curr Drug Targets 7: 1421-1434.

Kalkman HO (2006). The role of the phosphatidylinositide 3-kinase-protein kinase B pathway in schizophrenia. Pharmacol Ther 110: 117-134.

Kozlovsky N, Belmaker RH, Agam G (2002). GSK-3 and the neurodevelopmental hypothesis of schizophrenia. Eur Neuropsychopharmacol 12: 13-25.

Kozlovsky N, Nadri C, Agam G (2005). Low GSK-3beta in schizophrenia as a consequence of neurodevelopmental insult. Eur Neuropsychopharmacol 15: 1-11.

Kozlovsky N, Amar S, Belmaker RH, Agam G (2006). Psychotropic drugs affect Ser9-phosphorylated GSK-3 beta protein levels in rodent frontal cortex. Int J Neuropsychopharmacol 9: 337-342.

Kumar CC, Madison V (2005). AKT crystal structure and AKTspecific inhibitors. Oncogene 24: 7493-7501.

Lai WS, Xu B, Westphal KG, Paterlini M, Olivier B, Pavlidis P et al (2006). Aktl deficiency affects neuronal morphology and predisposes to abnormalities in prefrontal cortex functioning. Proc Natl Acad Sci USA 103: 16906-16911.

Lewis DA, Gonzalez-Burgos G (2006). Pathophysiologically based treatment interventions in schizophrenia. Nat Med 12: 1016-1022.

Linseman DA, Butts BD, Precht TA, Phelps RA, Le SS, Laessig TA et al (2004). Glycogen synthase kinase-3beta phosphorylates Bax and promotes its mitochondrial localization during neuronal apoptosis. J Neurosci 24: 9993-10002.

Mao Z, Bonni A, Xia F, Nadal-Vicens M, Greenberg ME (1999). Neuronal activity-dependent cell survival mediated by transcription factor MEF2. Science 286: 785-790.

Marshall J, Dolan BM, Garcia EP, Sathe S, Tang X, Mao Z et al (2003). Calcium channel and NMDA receptor activities differ- 
entially regulate nuclear $\mathrm{C} / \mathrm{EBPb}$ ta levels to control neuronal survival. Neuron 39: 625-639.

Morgan JI, Curran T (1986). Role of ion flux in the control of c-fos expression. Nature 322: 552-555.

Morris BJ, Cochran SM, Pratt JA (2005). PCP: from pharmacology to modeling schizophrenia. Curr Opin Pharmacol 5: 101-106.

Murphy TH, Worley PF, Baraban JM (1991). L-type voltagesensitive calcium channels mediate synaptic activation of immediate early genes. Neuron 7: 625-635.

Norton N, Williams HJ, Owen MJ (2006). An update on the genetics of schizophrenia. Curr Opin Psychiatry 19: 158-164.

Ohtsuki T, Inada T, Arinami T (2004). Failure to confirm association between AKT1 haplotype and schizophrenia in a Japanese case-control population. Mol Psychiatry 9: 981-983.

Olney JW, Farber NB (1995). Glutamate receptor dysfunction and schizophrenia. Arch Gen Psychiatry 52: 998-1007.

Papadia S, Stevenson P, Hardingham NR, Bading H, Hardingham GE (2005). Nuclear $\mathrm{Ca}^{2+}$ and the cAMP response elementbinding protein family mediate a late phase of activitydependent neuroprotection. J Neurosci 25: 4279-4287.

Rivero Vaccari JC, Casey GP, Aleem S, Park WM, Corriveau RA (2006). NMDA receptors promote survival in somatosensory relay nuclei by inhibiting Bax-dependent developmental cell death. Proc Natl Acad Sci USA 103: 16971-16976.

Ross CA, Margolis RL, Reading SA, Pletnikov M, Coyle JT (2006). Neurobiology of schizophrenia. Neuron 52: 139-153.

Rothman RB, Reid AA, Monn JA, Jacobson AE, Rice KC (1989). The psychotomimetic drug phencyclidine labels two high affinity binding sites in guinea pig brain: evidence for $N$-methyl-Daspartate-coupled and dopamine reuptake carrier-associated phencyclidine binding sites. Mol Pharmacol 36: 887-896.

Schwab SG, Hoefgen B, Hanses C, Hassenbach MB, Albus M, Lerer $B$ et al (2005). Further evidence for association of variants in the AKT1 gene with schizophrenia in a sample of European sib-pair families. Biol Psychiatry 58: 446-450.

Seeman P, Ko F, Tallerico T (2005). Dopamine receptor contribution to the action of PCP, LSD and ketamine psychotomimetics. Mol Psychiatry 10: 877-883.

Seeman P, Lasaga M (2005). Dopamine agonist action of phencyclidine. Synapse 58: 275-277.

Shelnutt SR, Gunnell M, Owens SM (1999). Sexual dimorphism in vitro metabolism and pharmacokinetics in rats. J Pharmacol Exp Ther 290: 1292-1298.

Song L, De Sarno P, Jope RS (2002). Central role of glycogen synthase kinase-3beta in endoplasmic reticulum stress-induced caspase-3 activation. J Biol Chem 277: 44701-44708.

Soriano FX, Papadia S, Hofmann F, Hardingham NR, Bading H, Hardingham GE (2006). Preconditioning doses of NMDA promote neuroprotection by enhancing neuronal excitability. J Neurosci 26: 4509-4518.
Sutton G, Chandler LJ (2002). Activity-dependent NMDA receptormediated activation of protein kinase B/Akt in cortical neuronal cultures. J Neurochem 82: 1097-1105.

Svenningsson P, Tzavara ET, Carruthers R, Rachleff I, Wattler S, Nehls $M$ et al (2003). Diverse psychotomimetics act through a common signaling pathway. Science 302: 1412-1415.

Szatmari E, Habas A, Yang P, Zheng JJ, Hagg T, Hetman M (2005). A positive feedback loop between glycogen synthase kinase 3 beta and protein phosphatase 1 after stimulation of NR2B NMDA receptors in forebrain neurons. J Biol Chem 280: 37526-37535.

Takadera T, Matsuda I, Ohyashiki T (1999). Apoptotic cell death and caspase-3 activation induced by $N$-methyl-D-aspartate receptor antagonists and their prevention by insulin-like growth factor I. J Neurochem 73: 548-556.

Takadera T, Ishida A, Ohyashiki T (2006). Ketamine-induced apoptosis in cultured rat cortical neurons. Toxicol Appl Pharmacol 210: 100-107.

Turner CP, Pulciani D, Rivkees SA (2002). Reduction in intracellular calcium levels induces injury in developing neurons. Exp Neurol 178: 21-32.

Vanhoutte P, Bading H (2003). Opposing roles of synaptic and extrasynaptic NMDA receptors in neuronal calcium signaling and BDNF gene regulation. Curr Opin Neurobiol 13: 366-371.

Wang C, Fridley J, Johnson KM (2005). The role of NMDA receptor upregulation in phencyclidine-induced cortical apoptosis in organotypic culture. Biochem Pharmacol 69: 1373-1383.

Wang C, Kaufmann JA, Sanchez-Ross MG, Johnson KM (2000). Mechanisms of $\mathrm{N}$-methyl-D-aspartate-induced apoptosis in phencyclidine-treated cultured forebrain neurons. J Pharmacol Exp Ther 294: 287-295.

Wang C, McInnis J, Ross-Sanchez M, Shinnick-Gallagher P, Wiley JL, Johnson KM (2001). Long-term behavioral and neurodegenerative effects of perinatal phencyclidine administration: implications for schizophrenia. Neuroscience 107: 535-550.

Wang CZ, Johnson KM (2005). Differential effects of acute and subchronic administration on phencyclidine-induced neurodegeneration in the perinatal rat. J Neurosci Res 81: 284-292.

Wang CZ, Johnson KM (2007). The role of caspase-3 activation in phencyclidine-induced neuronal death in postnatal rats. Neuropsychopharmacology 32: 1178-1194.

Yano S, Morioka M, Kuratsu J, Fukunaga K (2005). Functional proteins involved in regulation of intracellular $\mathrm{Ca}(2+)$ for drug development: role of calcium/calmodulin-dependent protein kinases in ischemic neuronal death. J Pharmacol Sci 97: 351-354.

Yoon WJ, Won SJ, Ryu BR, Gwag BJ (2003). Blockade of ionotropic glutamate receptors produces neuronal apoptosis through the Bax-cytochrome $c$-caspase pathway: the causative role of $\mathrm{Ca}^{2+}$ deficiency. J Neurochem 85: 525-533. 